\title{
EM BUSCA DE COISAS VIVIFICANTES DA MEMÓRIA ESCOLAR: A ESCOLA NORMAL E A ESCOLA DO MÁGISTÉRIO DE ÉVORA ${ }^{1}$
}

Teresa Santos*

\section{RESUMO}

Integrado na linha investigativa da cultura material escolar - expressão conceptual aplicada às acções e aos resultados dessas acções realizadas no âmbito da escola e destinadas a configurá-la -, este texto procura reconstituir a identidade e os percursos das extintas Escola Normal Primária e da Escola do Magistério Primário, de Évora. Adverte-se quer para o esquecimento decorrente da extinção quer para a pauperização da herança escolar comum e, neste sentido, enquadra-se no texto numa reflexão sobre o binómio memória/passado.

PALAVRAS-CHAVE: Escola Normal Primária de Évora. Escola do Magistério Primário de Évora. Memória. Arquivo.

\begin{abstract}
The article is an approach to carry out a survey of the documental, bibliographical material and iconographic sources of teacher training institutions in Évora (Normal Primary Schools and Primary Teacher Training Schools) and contribute towards their preservation and promotion. Prior goal is to let know the state of art about the history of theses two teacher education schools in the 19th and 20th centuries, produce narratives about their evolution and promote them in the scientific community.

${ }^{1}$ Parte do título, precisamente «Em busca de coisas vivificantes da memória escolar» foi usado num outro artigo, que se encontra no prelo. O seu uso é aqui propositado pois serve de mote às fases de pesquisa realizada sobre a Escola Normal de Évora e a Escola do Magistério Primário de Évora.

* Doutora em Filosofia da Educação e Professora da Universidade de Évora. Membro do Conselho Nacional de Educação para a Cidadania. Contato: msantos@uevora.pt
\end{abstract}


KEYWORDS: Normal Primary Schools in Evora. Primary Teacher Training Schools in Evora. Memory; Archive.

"E então? Quando a própria memória perde alguma coisa, como acontece quando nos esquecemos e procuramos recordar, onde é que por fim a encontramos, senão na própria memória?"

Santo Agostinho, Confissões, Lisboa, INCM, 2000, X, XIX, 28

\section{Nem sempre o que é óbvio é decisivo}

É óbvio que sem memória não há passado e que de uma curta memória do passado decorre um passado curto $^{2}$. Este raciocínio de identidade e reciprocidade coloca-nos perante a necessidade de vivificar a memória, distendendo assim o passado. Distendendo-o para lá da nossa circunstância temporal e determinação empírica; distendendo-o para um plano que é pertença de todos e por isso polissémico e plurívoco. Não se trata de um passado cronológico nem psicológico, mas de um passado com densidade ontológica pois nele se reúnem as narrativas da humanidade e nele se enovelam os sentidos dessas narrativas. Nada do passado é excedente ou se demarca da vida humana.

Decisivo é conservar a memória. A memória longa do passado longo. Decisivo por duas ordens de razão: uma, porque o passado constitui o substrato racional para interpretação do presente e invenção do futuro, projectando múltiplas possibilidades de conhecimento; outra, porque o passado manifesta a obra humana, quer dizer, a construção colectiva do mundo na qual todos/as cooperamos, bem ou mal, conscientes disso ou inconscientes. Não se trata de uma manifestação fáctica, estruturada e definitiva da obra humana, mas de um processo de presentificação do identificado, quer dizer, um processo indissociavelmente evocativo, sempre parcial, insuficiente e transfigurativo, realizado na justa medida das capacidades pessoais e dos documentos disponíveis. Por tudo isto, o

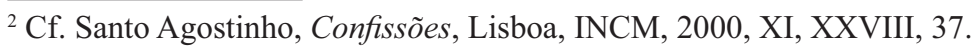


passado conservado na memória, repassado de historicidade, é correlato de um processo aberto, retomável, refazível e narrativo.

Sendo óbvia a indissolubilidade do binómio memória-passado e sendo decisivo conservar o passado para dar sentido e continuidade à tarefa humana de construir o mundo, por que razão se afirmou, no título deste articulado de parágrafos, que "nem sempre o que é óbvio é decisivo"? De facto, entre o óbvio e o decisivo interpõem-se a inércia, a má-vontade e a incúria. Seria óbvio que todos os documentos relativos à Escola Normal Primária e à Escola do Magistério Primário tivessem sido conservados e estimados por fazerem parte da presença substancial do passado de uma comunidade. Infelizmente a inércia, a má-vontade e a incúria prevaleceram, conduzindo à desvalorização, ao desinteresse e ao esquecimento das duas instituições de formação de professores do ensino primário. Já se denunciou esta situação, em artigo que se encontra no prelo. Agora reforça-se a denúncia. O que causa perplexidade é saber que a instituição responsável pela memória estas duas escolas se desresponsabilizaram inteiramente, como se estas fossem corpos estranhos a rejeitar.

Não foi pois por acaso que se transcreveu a frase de Santo Agostinho colocada em epígrafe. Ela exorta a regressar à memória quando a memória foi varrida pelo esquecimento. Paradoxal este conselho agostineano? Apenas na forma. Significa tentar nova abordagem e tomar outro percurso para vivificar a memória. Tal é o que aqui se intenta.

\section{O percurso tomado}

Toda a investigação traça um percurso. Um percurso não linear nem meramente cumulativo. Por isso inflecte sobre si mesmo para corrigir e completar informações, para dar consistência a raciocínios, para correlacionar conceitos e até para desconstruir ideias feitas. Tal vaivém faz parte da dinâmica investigativa e de uma hermenêutica circular que visa fundamentar, alargar e transversalizar cada vez mais os dados e a reflexão. Ora, como se referiu acima, este artigo corresponde a nova tentativa de abordagem da Escola Normal Primária e da Escola do Magistério Primário, estabelecidas em Évora. Se numa primeira fase se procedeu à localização 
das fontes oficiais, ao registo e análise documental - do investimento resultou uma tremenda deceptividade -, agora investe-se em nova fonte: os jornais. O critério de selecção foi elementar: delimitação institucional e regional. Para trabalhar a Escola Normal escolheram-se, para já, os jornais A Escola e O Manuelino d'Évora, para a Escola do Magistério seleccionouse $A$ Democracia do Sule $O$ Leme. Dois jornais escolares e dois jornais citadinos de maior representatividade local.

Como tipo de fonte os jornais têm características particulares associadas ao material de suporte e à imediaticidade da informação. De suporte frágil - o papel - e de préstimo informativo delimitado temporalmente - as notícias são voláteis e sobrepõem-se umas às outras -, os jornais são fontes incompletas. Em todo o caso configuram um percurso possível do qual a investigação não prescinde.

Da leitura dos jornais, uma leitura em progresso ou inconcluída, resulta a narração de dois momentos da vida das duas escolas. Na medida do possível tenta-se unificar a vida das escolas num todo, figurando-as, avaliando a sua acção e sentido apreço por elas.

Segue-se uma metodologia de proximidade. Dito assim, devese uma explicação aos historiadores da educação. "Metodologia de proximidade" não corresponde a nenhum instrumento analítico. Não existe. O que aconteceu é que a informação obtida sugeriu logo pontos de afinidade entre as duas instituições - coincidências e paralelismos -, causando um efeito comparativo. Todavia não se procede metodologicamente por comparação, inferindo semelhanças e estabelecendo generalizações de modo a destacar a singularidade, a heterogeneidade e a complexidade de instituições educativas. Tão-só se aproximam duas instituições com identidade própria e circunstância distinta (garantia da alteridade) mas com o mesmo fim, sujeitas a fortes tensões ideológicas e nutridas interiormente por utopias confiantes no progresso personalista e social. É essa proximidade, quase lúdica, que estrutura esta narrativa histórica do ciclo de vida de cada escola. 


\section{O ciclo de vida da Escola Normal Primária de Évora}

\subsection{O acontecimento inaugural}

É da figuração dos acontecimentos inaugurais que se impõe partir. Assim há a registar que a Escola Normal de Évora foi criada por decreto de 6 de Março de 1884, publicado no Diário do Governo n. ${ }^{\circ} 62$ de 17 do mesmo mês e ano ${ }^{3}$. Os preparativos para a efectivação começaram de imediato como se confirma na correspondência trocada entre a Comissão Executiva da Junta Distrital e o Governador Civil, por um lado, e, por outro, entre este e a Direcção Geral de Instrução Pública. Preocupações imediatas foram a aquisição de edifício e de recheio específico.

$\mathrm{O}$ edifício escolhido foi a extinta Igreja Paroquial de S. Pedro ${ }^{4}$, propriedade camarária em consequência do processo de secularização ocorrido no último quartel do século XIX ${ }^{5}$. Todavia o edifício, requalificado,

\footnotetext{
${ }^{3}$ A descentralização das Escolas Normais por distrito decretada por Rodrigues Sampaio (lei de 2 de Maio de 1878) não foi inteiramente concretizada. Apenas foi criada a escola de Évora. A inércia mereceu o seguinte comentário de Ferreira Deusdado: "A lei de 2 de maio de 1878 criou, em todos os distritos, escolas normais de ensino primário, mas, até esta data, ainda tais escolas, com pequeníssimas excepções, não se fundaram nem abriram." (cf. Ferreira Deusdado, p. 335 e 342 [apud Rómulo de Carvalho, História do Ensino em Portugal: desde a fundação da nacionalidade até ao fim do regime de SalazarCaetano, Lisboa, Fundação Calouste Gulbenkian, 1986. p. 623]). A lei de 2 de maio de 1878 possibilitava a abertura de quatro Escolas Normais de $1^{\text {a }}$ classe, duas masculinas e duas femininas, em Lisboa e Porto, uma de $2^{\mathrm{a}}$ classe por cada capital de distrito. Esta lei foi modificada por José Luciano de Castro em 1880, tendo sido regulamentada no ano seguinte por Rodrigues Sampaio, quando voltou a ocupar a pasta de ministro do reino.

${ }^{4}$ Sobre a igreja esclarece Túlio Espanca: "Antiga Comenda dos Templários, por abolição desta Ordem Militar, foi transformada em freguesia urbana sob beneplácito real de D. Dinis e do bispo D. Geraldo Domingues como priorado de seis benefícios dependentes da metrópole, pois as suas rendas e proventos eram altos" (cf. Túlio Espanca Inventário Artístico de Portugal. Concelho de Évora, I Vol., Lisboa, Academia Nacional de Bellas-Artes, 1966, p. 52).

5 Ainda Túlio Espanca: "Em 1841, a transferência da sede de freguesia para a monumental Igreja de S. Francisco deu o golpe de misericórdia ao edifício religioso, que passou por obras vultuosas para ser adaptada a Escola Distrital e mais tarde a Escola Normal e Primária Superior André de Resende. Pertence à Câmara Municipal" (cf. Idem, p. 53).
} 
requeria obras que apropriassem o espaço às novas funções, das quais ficou encarregado o Eng. ${ }^{\circ}$ Pelouro e posteriormente do Eng. ${ }^{\circ}$ Pinho. Talvez por exagero ou devido à habitual ênfase jornalística, $O$ Manuelino d'Évora informava ter sido "o sr. Pelouro o primeiro que empregou em Évora, e cremos que no país, as vigas de ferro em duplo T" e novidade distinguiam o edifício escolar e, directamente, valorizavam a instituição e a sua função.

A escola integrava uma biblioteca e gabinetes de física e química ${ }^{8}$, tendo Adolfo Coelho ${ }^{9}$ sido consultado sobre o conteúdo adequado, conforme um jornal local noticiava: "[...] recorreu [Comissão Executiva] também aos prudentes avisos do ilustrado professor do curso superior de letras o exmo. sr. Francisco Adolfo Coelho, que se dignou aceitar o nosso convite para nos encaminhar na aquisição dos objectos mais indispensáveis." 10 .

A complementar os dois espaços de apoio didáctico e pedagógico - biblioteca; gabinetes de física e química - organizou-se um museu que reforçava o ensino pela visualização do real e concreto. Numa carta de 22

${ }^{6}$ Sobre este último informa-se a sua categoria: “(...) condutor de $1 .{ }^{\text {a }}$ classe servindo de 2. ${ }^{\circ}$ engenheiro na repartição distrital" (cf. O Manuelino d'Évora, de 21 de Outubro de 1885 , p. 2).

${ }^{7}$ Cf. Idem, p. 2. Também o artigo «Apontamentos para a história da Escola Normal de Évora» publicado no jornal A Escola [n. ${ }^{\circ} 13$ (1 Março 1886) pp. 102-103] transcreve parcialmente o Relatório da Comissão Executiva da Junta Geral de 1885 sobre as obras de recuperação da Igreja de São Pedro.

${ }^{8}$ A 15 de Fevereiro o Secretário de Estado do Reino escrevia ao Governador Civil da cidade: "Para se poder abrir no próximo mês de Outubro, como é conveniente, a escola normal desta cidade, faz-se necessário que V. Exa. se sirva informar com urgência se, além do edifício, estará para aquela época pronta toda a mobília e utensílios precisos para o estudo e para os exercícios escolares, e bem como assim a biblioteca e os gabinetes de física e química poderão estar organizados para então; e, finalmente, se no orçamento da Junta Geral para o corrente ano foram votadas as verbas para o pagamento das pensões, prémios aos alunos e expediente das aulas, especificando essas verbas" (cf. Fundo do Governo Civil de Évora, Peça 6/1884 CX 1690).

${ }^{9}$ Francisco Adolfo Coelho (15/01/1847 - 09/02/1919) que foi uma das figuras mais importantes da intelectualidade portuguesa dos finais do século XIX.

${ }^{10}$ Cf. O Manuelino d'Évora (21 Outubro 1885) p. 2. Encontra-se na Biblioteca Nacional um exemplar do livro de Saffray, que servia de referência à organização do museu. Tratase de Leçon des Choses: cours méthodique (5ème éd., Paris, Hachette, 1882). 
de Fevereiro de 1884, emitida pela Junta Geral do Distrito enumeram-se as peças necessárias a proporcionar "lições de coisas", entre elas as contidas no museu-caixa de Saffray: "[...] 700 espécimes de produtos naturais e artificiais relativamente á alimentação - ao vestuário - ao calor - a luz - a mineralogia - a cerâmica - as madeiras, etc". ${ }^{11}$ Acrescentavam-se exemplares representativos da região, o bastante para conhecer a realidade local: "diversas espécies de terreno - argiloso - calcário - silicioso e humoso, pelas rochas, e minerais, pelas suas diversas espécies de madeiras, de combustão e de construção, e de outros produtos animais, vegetais ou minerais, antes ou depois de manipulados.". ${ }^{2}$ No quadro dos recursos materiais sabe-se pelo jornal A Escola que a Comissão Executiva comprou um 'harmonium' para a aula de canto coral e que a Junta Geral comprou os utensílios e a mobília para a escola, elegendo o modelo Lenoir aperfeiçoado. ${ }^{13}$

Os recursos humanos contavam com o corpo docente, o professor da escola anexa, que usufruía de habitação, e o porteiro. ${ }^{14}$ A relação professores/disciplinas era a seguinte:

\footnotetext{
${ }^{11}$ A carta está assinada por António Pereira da Silva, Manuel Joaquim da Costa Silva e José Fernando Pereira. Rogério Fernandes informa: " [...] entre as primeiras referências em Portugal à criação de um Museu Pedagógico, acham-se as de Francisco Adolfo Coelho (1847-1919), na fase em que, junto da Câmara Municipal de Lisboa, se ocupou activamente da formação de uma instituição de ensino primário superior, entre os anos de 1882-1883" (cf. Rogério Fernandes, «A História e os seus registos. Que fazer com este museu?», in FELGUEIRAS, Margarida, A Escola Primária: entre a Imagem e a Memória, Porto, s.e., 2000, p. 73). No jornal A Escola encontra-se um artigo intitulado «Os museus escolares», assinado por J. C. Carvalho Saavedra [n. 133, (quinta-feira, 22 Maio 1890) p. 2-3]; n. 134 (quinta-feira, 29 Maio 1840) p. 2-3].

${ }^{12} \mathrm{Idem}$.

${ }^{13} \mathrm{Cf}$. «Apontamentos para a história da Escola Normal d'Évora», A Escola, n. 13 (1 Março 1886) p. 102-103. Sobre o modelo Lenoir consultar: LENOIR, Mobilier des Écoles. Systeme Lenoir, Paris, Lenoir, 1879.

${ }^{14}$ Cf. A Escola, n. 133 (quinta-feira, 22 Maio 1890) p. 2.
} 


\section{Quadro 1}

Professores/as

\begin{tabular}{|l|l|l|l|}
\hline Cadeira & Disciplinas & Docente & Cargo \\
\hline $1 .^{\text {a }}$ & $\begin{array}{l}\text { Física, Química, Introdução, Desenho, } \\
\text { Higiene, Economia rural }\end{array}$ & $\begin{array}{l}\text { Dr. João Augusto de } \\
\text { Pina }^{15}\end{array}$ & Director \\
\hline $2 .^{\text {a }}$ & $\begin{array}{l}\text { Aritmética, Geometria, Agricultura, } \\
\text { Escritura comercial }\end{array}$ & $\begin{array}{l}\text { Possidónio José da } \\
\text { Silva }\end{array}$ & $\begin{array}{l}\text { Bibliote- } \\
\text { cário }\end{array}$ \\
\hline $3 .^{\text {a }}$ & $\begin{array}{l}\text { Geografia, arologia, História, Língua } \\
\text { francesa, Caligrafia }\end{array}$ & $\begin{array}{l}\text { Henrique Augusto da } \\
\text { Cunha Soares Freire }\end{array}$ & Secretário \\
\hline $4 .^{\text {a }}$ & $\begin{array}{l}\text { Leitura, Gramática, Moral, Pedagogia, } \\
\text { Metodologia, Legislação escolar, } \\
\text { Direitos e Deveres }\end{array}$ & $\begin{array}{l}\text { Dr. José Lopes } \\
\text { Marçal }\end{array}$ & $\begin{array}{l}\text { Professor } \\
\text { auxiliar }\end{array}$ \\
\hline $5 .^{\text {a }}$ & Canto coral & $\begin{array}{l}\text { Helidoro Vargas } \\
\text { Júnior }\end{array}$ & - \\
\hline $6 .^{\text {a }}$ & Ginástica, Regente de Prática & Henrique Freire & - \\
\hline
\end{tabular}

A imprensa local publicitou no dia 28 de Abril a abertura do concurso "por um espaço de trinta dias a começar em 28 do corrente [Abril] para admissão a dita escola de 20 alunos pensionistas e de alunos não pensionistas". ${ }^{17}$ No dia seguinte, outra notícia vinha precisar que as provas públicas constavam de uma parte escrita e outra oral sobre matérias de instrução primária. ${ }^{18}$

${ }^{15}$ Nota biográfica: João Augusto de Pina, natural de Alvoco da Serra (Concelho de Ceia), bacharel formado em Teologia e professor do Liceu de Évora. Deslocou-se ao parlamento em 1887 para defender os professores primários (cf, «Os professores da Escola Normal no Parlamento», A Escola, (quarta-feira, 30 Março 1887) p. 2).

16 Nota biográfica: Henrique Augusto da Cunha Soares Freire [18/07/1842 $\neg$ ?/11/1908] formou-se na Escola Normal de Marvila. Em 1884 fundou, em Lisboa, a revista pedagógica A Escola. No ano seguinte, por ter sido nomeado professor da Escola Normal de Évora, a revista passou a ser aí publicada. Em 1902 foi transferido para o círculo escolar de Beja devido ao encerramento da escola.

${ }^{17}$ Cf. Fundo do Governo Civil de Évora Peça 6/1884 CX 1690.

${ }^{18}$ Cf. «Escola Normal d' Évora», O Manuelino d' Évora, Ano IV, n. ${ }^{\circ} 171$ (29 abr. 1884) p. 2. O anúncio acrescentava a seguinte informação: "Os admitidos ficam com $6 \$ 000$ réis mensais, compêndios, papel e outros objectos precisos ao estudo; ficando obrigados ao magistério público por seis anjos A este concurso também são admitidos alunos sem pensão. Os professores oficiais em exercício podem seguir o curso normal; são dispensados de exame de admissão, não pagam propinas, e vencem o ordenado por 
Recuperado e adaptado o edifício, obtidos os recursos materiais, assegurados os recursos humanos e formada a turma, a Escola Normal de Évora, a primeira no país de $2^{\text {a }}$ classe e que habilitava professores do sexo masculino para o $1 .^{\circ}$ e $2 .^{\circ}$ grau, foi inaugurada a 16 de Outubro de $1885,{ }^{19}$ quando era Ministro do Reino Barjona de Freitas, ${ }^{20}$ com a pompa adequada à circunstância, merecendo notícia de primeira página. No jornal O Manuelino d' Évora, de 21 de Outubro de 1885, o facto foi destacado e mereceu descrição pormenorizada, permitindo à imaginação do leitor a reconstituição da cerimónia:

Na quinta-feira, 16 do corrente, aniversário de S. M. a Rainha, inaugurouse a Escola Normal. A festa escolar concorreram representantes de todas as classes, de todas as cores políticas. Pelo meio-dia abriu-se a sessão inaugural na grande sala, destinada a escola primária anexa; presidia o exmo. Governador civil, conde da Costa, tendo a seu lado na mesa da presidência o sr. Queiroga ${ }^{21}$ inspector da $9^{\mathrm{a}}$ circunscrição, e o sr. Padre Pina, professor do Liceu e director da Escola. Estavam presentes os membros da Comissão Executiva da Junta Geral, a Câmara Municipal, representantes dos corpos administrativos, o provedor do Ministro, chefe do estado-maior, delegado de saúde, governador do arcebispado, vicereitor do seminário, Dr. delegado, etc. À esquerda da presidência estava o

inteiro se deixarem á sua custa uma pessoa habilitada que os substitua na regência das cadeiras." O anúncio estava conforme o regulamento de 28 de Julho de 1881 . Recordese que a lei de 2 de Maio de 1878 fora modificada por José Luciano de Castro em 1880, tendo sido regulamentada no ano seguinte por Rodrigues Sampaio quando voltou a ocupar a pasta de ministro do reino.

${ }^{19}$ Em Sessão Camarária de 1 de Maio de 1884 fora anunciado, pelo Presidente da Comissão Executiva da Junta Geral Distrital, a abertura da escola para o dia 1 de Outubro desse ano [cf. «Escola Normal», O Manuelino d' Évora, n. ${ }^{\circ} 171$ (27 mai. 1884) p.1]. Observe-se que um ano antes o mesmo jornal publicava um artigo da autoria de Francisco Pedro, intitulado «Magistério Primário», exigindo uma formação de maior qualidade para as escolas do magistério [cf. O Manuelino d'Évora, n. 197 (28 out. 1884) p. 1.2 e n. 198 (nov. 1884) p. 2].

${ }^{20}$ Augusto César Barjona de Freitas [13/ 01/ $\underline{1834}$ - 23/07/1900] foi membro do partido Regenerador e ministro.

${ }^{21}$ Domingos de Brito Queiroga era o inspector da 9. circunscrição escolar ou, se se preferir, do círculo escolar de Évora. 
pessoal da Escola Normal. Bastantes senhoras honraram e abrilhantaram a inauguração com a sua presença. Logo que se instalou a mesa da presidência, o digno governador civil deu orem para deixar livre a entrada e em breve se encheu o vasto salão. A ornamentação era singela mas apropriada; nas paredes alguns mapas; ao fundo uma grande moldura de entalhado dourado com uma pintura que será conveniente substituir; mais baixo um retrato de S. M. a Rainha; aos lados os bustos d'el rei e de D. Pedro V:22 nos vãos das janelas Grandes vasos com Flores. A musica da Casa Pia formou no primeiro vestíbulo, onde executou alguns trechos; entrou depois no salão para tocar o huno oficial..$^{23}$

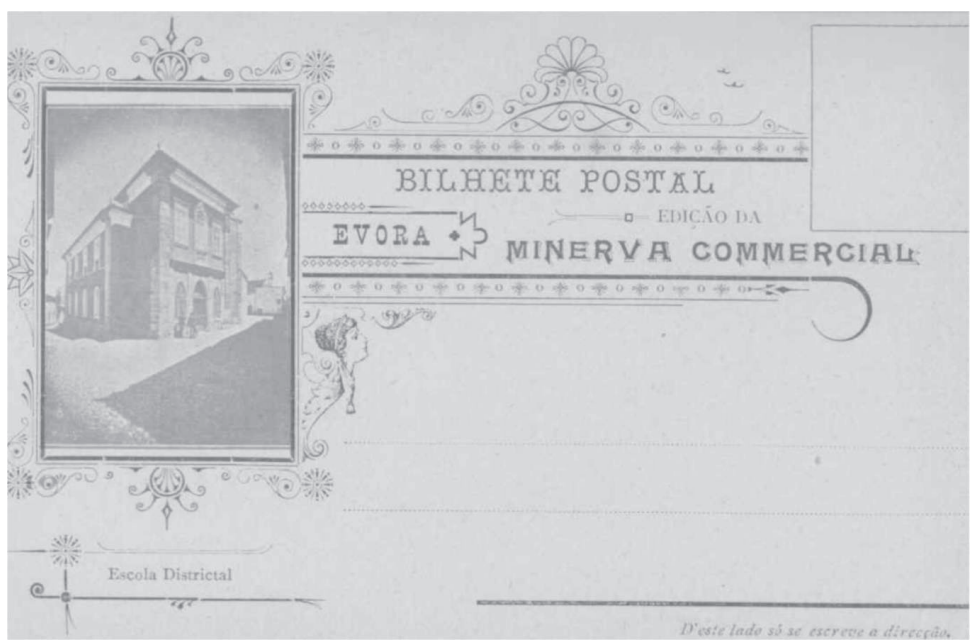

FIGURA 1 - Extinta Igreja Paroquial de S. Pedro onde funcionou a Escola Normal de Évora e depois a Escola Distrital

\footnotetext{
${ }^{22}$ Os bustos existiam na Escola do Magistério mas desapareceram no período de transição do legado para a universidade.

${ }^{23}$ Cf. «Escola Normal», O Manuelino d'Évora, n. ${ }^{\circ} 1$ (21 out. 1884) p.1. Consultar também «Apontamentos para a história da Escola Normal d'Évora», A Escola, n. ${ }^{\circ}$, (1 janeiro 1885) p. 36.
} 


\subsection{Encerramento, reabertura e ...}

Da extinção do Ministério da Instrução em 1892 (em funcionamento entre Abril de 1890 e Março de 1892) decorreu o encerramento das escolas normais, exceptuando as quatro de $1^{\mathrm{a}}$ classe. Por conseguinte, também a Escola Normal de Évora, custeada pela Junta Geral do Distrito, foi abrangida pela medida reducionista ${ }^{24}$. Maria Filomena Mónica registou uma interessante reacção conservadora: "[...] o símbolo supremo das ambições e da fé republicana na educação foi aniquilado: esse foco de indisciplina e de imoralidade, onde os alunos aprendiam, acusava o reaccionário jornal $A$ Educação Nacional, que «o filho se pode revoltar contra o pai», desapareceu da face da terra". ${ }^{25}$

O impacte do encerramento foi forte, quer na vida pessoal quer na vida comunitária. Durante sete anos a escola interagira com vários sectores da comunidade, valorizando regional a identidade cultural. Mas foi um impacte que a prudência silenciou, como denuncia uma notícia publicada na revista $A$ Escola e parcialmente reproduzida no jornal citadino $O$ Manuelino d'Évora. ${ }^{26}$ Tal prudência explica a ausência de notícias sobre o assunto. De facto, a única notícia encontrada até ao momento surgiu dois meses depois da data oficial em que supostamente deveriam ter começado as aulas, ou seja, quando o encerramento era irreversível. Substancialmente a notícia transcreve a uma outra publicada em Lisboa. Esta começa por justificar o silêncio: "Conhecemos o terreno que pisamos, tem-no-lo ensinado as duras lições da experiência [...]". ${ }^{27}$ Em relação à situação de desemprego que afectou Henrique Freire, lê-se a seguir: "[...] esbulhado

24 No primeiro estudo que fizemos sobre esta instituição afirmámos, segundo informação não confirmada, (Carlos Fontes) que a Escola Normal de Évora só havia fechado em 1896, sendo de imediato reaberta. A consulta de periódicos regionais e educacionais corrigem a informação.

${ }^{25}$ Cf. Maria Filomena Mónica, Educação e Sociedade no Portugal de Salazar (A escola primária salazarista, 1926-1939), Lisboa, Editorial Presença/Gabinete de Investigações Sociais, 1978, p. 211-212.

${ }^{26}$ Cf. «Escola Normal», O Manuelino d'Évora, n. 606 (4 Dez. 1892) p. 2. A notícia não está assinada.

${ }^{27}$ Idem. 
violentamente do lugar onde ganhava o pão, depois de 25 anos de serviço, dos quais 8 nesta ESCOLA NORMAL - isto é, desde a sua inauguração." Acusa e responsabiliza sem citar nomes: "[...] a Escola Normal d'Évora está morta e [foi trucidada pela] má vontade de alguns espíritos que obcecados pela vingança, ou pela ignorância, $[\ldots .$. ]". Ironiza o encerramento e classifica-o como "torpíssima comédia-drama, que terminou por privar do pão quotidiano alguns; que defraudou o comercio e a população no meio da crise geral, em que alguns contos de réis e que em fim do século XIX, o século das luzes (!) fechou uma instituição de educação e ensino, utilíssimo: acabou com essa universidade popular $[\ldots]^{28}$ "

Independentemente das considerações de valor subjectivo do articulista, importa referir que Portugal, nos finais do século XIX, teve uma atmosfera política especialmente indutora da instabilidade social e da debilidade económica, provocando múltiplas iniciativas reformistas e contra-reformistas. Os factores, em convergências, eram de vária ordem: a crise política instalada desde o Ultimatum Inglês, a crise económica que afectava a maioria e levava à realização de greves, a corrupção política, a propaganda republicana de cunho positivista e evolucionista e a reacção encabeçada pelo episcopado português e correligionários monárquicos. As instituições, os serviços e a população ressentiam-se da crise. Ora, sendo certo que a escola resiste pouco a crises, a sua presença trémula e intermitente é compreensível mas lamentável. A escola de Évora não podia estar descontextualizada da crise geral, por melhor que fosse a vontade local e o empenho dos professores.

Quatro anos depois, quando João Franco ${ }^{29}$ ocupava a pasta do reino, a escola reabriu ao abrigo do decreto de 18 de Junho de $1896 .{ }^{30} \mathrm{~A}$ reabertura pode ser confirmada em três fontes, para além do decreto. O jornal

${ }^{28}$ A expressão 'universidade popular' pertence a um jornalista de El Monitor de Primera Enseñança, publicado em Barcelona.

${ }^{29}$ Nota biográfica: João Ferreira Franco Pinto Castelo Branco [14/02/1855 - 1922] foi ministro do reino no governo de Hintze Ribeiro, de 23 de Fevereiro de 1893 a 7 de Fevereiro de 1897.

${ }^{30}$ Existe na Secção dos Reservados da Biblioteca Geral da Universidade de Évora o $1^{\mathrm{o}}$ volume do Regulamento do Ensino Primário Aprovado por decreto de 18 de Junho 1896 (Lisboa, Imprensa Nunes, 1896).

Educ. e Filos. Uberlândia, v. 23, n. 46, p. 73-98, jul./dez. 2009. 
O Manuelino d'Évora publicou, a 23 de Maio de 1897, a seguinte notícia:

Em harmonia com o art. $^{\circ} 135$. $^{\circ}$ do regulamento geral do ensino primário de 18 de Junho de 1896, começou no sábado 15 e termina no dia 15 de Junho próximo o prazo para a entrega dos requerimentos dos candidatos que pretendem ser admitidos a exame para o magistério primário. Este exame só se pode fazer perante as escolas normais de Lisboa e Porto, e as distritais de Évora e Viloa Real. Os candidatos estão sujeitos à propina de $3 \$ 000$ reis, segundo uma portaria de 10 de corrente mês". ${ }^{31}$

Um mês depois, no livro Candidatos ao Magistério. Escola Distrital d'Évora. Mapa de Exames dos Candidatos à Habilitação para o Magistério Primário Elementar, ${ }^{32}$ registavam-se os nomes e as classificações de 39 pessoas, das quais 18 foram aprovadas. Também o livro Curso para o Magistério. Escola Distrital d'Évora. Notas de frequência, ${ }^{33}$ onde mensalmente eram lançadas as notas de alunos/as matriculados/as no ano lectivo de 1896/1897, confirmava o início das aulas em Outubro. A turma era constituída por 10 estudantes. Neste livro estão também indicados os nomes dos professores, embora os nomes não estejam associados a disciplinas. Observe-se o quadro:

${ }^{31}$ Cf. O Manuelino d' Évora, Ano XVII, no 822 (23 Mai.) 1897, p. 2.

${ }^{32}$ No Termo de Abertura pode-se ler: "Este livro servirá para mapa das classificações obtidas no exame da habilitação ao magistério primário elementar pelos candidatos estranhos". Está datado de 15 de Julho de 1897 e assinado pelo Secretário da Escola Distrital de Évora que era o Comissário da Inspecção Primária, António Maria [...?]. O livro formato rectangular $(\mathrm{a}=32 / \mathrm{h}=46)$. Das 94 páginas, todas rubricadas, apenas 5 estão preenchidas. A prova escrita integrava as disciplinas de Ditado, Caligrafia, Desenho, Problemas e Questões. A prova prática era constituída por Língua Portuguesa, Aritmética, Geometria, Escrituração, Ciências naturais, História, Moral e Direito, Deveres dos Cidadãos, Economia, Pedagogia. A prova prática incidia sobre a Regência de classes. Acrescia Canto, Ginástica e Lavores.

${ }^{33} \mathrm{O}$ Termo de Abertura foi redigido pelo director da escola, José Maria de Queiroz Veloso: "Este livro, que vou por mim devidamente rubricado em todas as suas folhas, servirá para Heller se lançarem as notas da frequência, aproveitamento e comportamento dos alunos do curso de habilitação ao magistério". A data é de 30 de Outubro de 1896. O livro tem capa em cartão com lombada e cantos reforçados a tecido tipo sarja e tem formato rectangular $(\mathrm{a}=45,5 / \mathrm{h}=29)$. Das 201 páginas apenas 105 estão preenchidas. As datas vão de $30 \mathrm{de}$ Outubro de 1896 até 1 de Julho de 1903.

Educ. e Filos. Uberlândia, v. 23, n. 46, p. 73-98, jul./dez. 2009. 
Quadro 2

Professores/as

\begin{tabular}{|c|c|c|c|c|c|c|}
\hline 1896-97 & $1897-98$ & 1898-99 & 1899-00 & 1900-01 & 1901-02 & 1902-03 \\
\hline $\begin{array}{l}\text { José } \\
\text { Maria de } \\
\text { Queiroz } \\
\text { Veloso }^{34}\end{array}$ & $\begin{array}{l}\text { José } \\
\text { Maria de } \\
\text { Queiroz } \\
\text { Veloso }\end{array}$ & $\begin{array}{l}\text { José } \\
\text { Maria de } \\
\text { Queiroz } \\
\text { Veloso }\end{array}$ & $\begin{array}{l}\text { José } \\
\text { Maria de } \\
\text { Queiroz } \\
\text { Veloso }\end{array}$ & $\begin{array}{l}\text { Joaquim } \\
\text { António } \\
\text { Simões }\end{array}$ & $\begin{array}{l}\text { José da } \\
\text { Costa } \\
\text { Henriques }\end{array}$ & $\begin{array}{l}\text { José da } \\
\text { Costa } \\
\text { Henriques }\end{array}$ \\
\hline $\begin{array}{l}\text { António } \\
\text { José } \\
(\ldots)\end{array}$ & $\begin{array}{l}\text { António } \\
\text { José } \\
(\ldots)\end{array}$ & $\begin{array}{l}\text { António } \\
\text { José } \\
(\ldots)\end{array}$ & $\begin{array}{l}\text { José da } \\
\text { Costa } \\
\text { Henriqes }\end{array}$ & \begin{tabular}{|l|} 
José \\
Maria de \\
Queiroz \\
Veloso
\end{tabular} & \begin{tabular}{|l|} 
Luís \\
António \\
G. Moraes \\
Sarmento
\end{tabular} & $\begin{array}{l}\text { Luís An- } \\
\text { tónio G. } \\
\text { Moraes } \\
\text { Sarmento }\end{array}$ \\
\hline $\begin{array}{l}\text { Maria das } \\
\text { Mercês } \\
\text { Aguado } \\
\text { Formosinho }\end{array}$ & $\begin{array}{l}\text { Maria das } \\
\text { Mercês A. } \\
\text { Formosi- } \\
\text { nho }\end{array}$ & $\begin{array}{l}\text { Maria das } \\
\text { Mercês A. } \\
\text { Formosi- } \\
\text { nho } \\
\end{array}$ & $\begin{array}{l}\text { Maria das } \\
\text { Mercês A. } \\
\text { Formosi- } \\
\text { nho }\end{array}$ & $\begin{array}{l}\text { Maria das } \\
\text { Mercês A. } \\
\text { Formosi- } \\
\text { nho } \\
\end{array}$ & $\begin{array}{l}\text { Joaquim } \\
\text { António } \\
\text { Simões }\end{array}$ & $\begin{array}{l}\text { Joaquim } \\
\text { António } \\
\text { Simões }\end{array}$ \\
\hline $\begin{array}{l}\text { Luís } \\
\text { António } \\
\text { Galvão } \\
\text { Moraes } \\
\text { Sarmento }\end{array}$ & $\begin{array}{l}\text { Luís } \\
\text { António } \\
\text { G. Moraes } \\
\text { Sarmento }\end{array}$ & \begin{tabular}{|l|} 
Luís \\
António \\
G. Moraes \\
Sarmento
\end{tabular} & \begin{tabular}{|l|} 
Luís \\
António \\
G. Moraes \\
Sarmento \\
\end{tabular} & \begin{tabular}{|l|} 
Luís \\
António \\
G. Moraes \\
Sarmento
\end{tabular} & $\begin{array}{l}\text { Maria das } \\
\text { Mercês A. } \\
\text { Formosi- } \\
\text { nho }\end{array}$ & $\begin{array}{l}\text { Maria das } \\
\text { Mercês A. } \\
\text { Formosi- } \\
\text { nho }\end{array}$ \\
\hline $\begin{array}{l}\text { Alfredo } \\
\text { das Neves } \\
\text { Júnior }\end{array}$ & $\begin{array}{l}\text { Alfredo } \\
\text { das Neves } \\
\text { Júnior } \\
\end{array}$ & $\begin{array}{l}\text { Alfredo } \\
\text { das Neves } \\
\text { Júnior } \\
\end{array}$ & $\begin{array}{l}\text { Salvadora } \\
\text { da Luz } \\
\text { Mosca }^{35} \\
\end{array}$ & \begin{tabular}{|l|} 
Salvadora \\
da Luz \\
Mosca \\
\end{tabular} & \begin{tabular}{|l|} 
Salvadora \\
da Luz \\
Mosca \\
\end{tabular} & $\begin{array}{l}\text { Salvadora } \\
\text { da Luz } \\
\text { Mosca } \\
\end{array}$ \\
\hline- & - & $\begin{array}{l}\text { Salvadora } \\
\text { da Luz } \\
\text { Mosca }\end{array}$ & - & - & - & - \\
\hline
\end{tabular}

Os dois livros comprovam igualmente o último ano de funcionamento, precisamente 1903. O percurso da Escola Normal Primária de Évora é desconhecido a partir deste ano. Fechou por falta de alunos?

${ }^{34}$ José Maria de Queiroz Veloso [29/09/1860 - 31/10/1952] licenciou-se em Medicina na Escola Médico-Cirúrgica do Porto. Em 1895 tornou-se professor Liceu de Évora, tendo exercido a função de Director da Escola Normal.

${ }^{35} \mathrm{O}$ nome de Salvadora Mosca aparece duas vezes na lista de alunas aprovadas nos exames de habilitação ao magistério primário (cf. A Escola n. 36 [15 Dez. 1887] p.3. Nos exames de $1^{\circ}$ grau obteve a classificação de Bom (7 valores numa escala de 10) e no exame de $2^{\circ}$ grau foi classificada com Suficiente (5 valores). Por conseguinte, ela fora aluna da escola, no primeiro período de funcionamento. 
Ou fechou por pressão governativa? Não há dados disponíveis. Algo a pesquisar por outras vias, embora não promissoras. Todavia é útil saber-se que os decretos foram sucedendo no período republicano com a voracidade já familiar na monarquia. ${ }^{36} \mathrm{O}$ decreto de 29 de Março de 1911 previa Escolas Normais Primárias em Lisboa, Porto e Coimbra, introduzindo o regime coeducativo e funcionando em externato, com expectativas de evoluírem para internato. A essas escolas seriam anexadas diversas instituições auxiliares (art. ${ }^{\circ} 114^{\circ}$ ), num desmedido rasgo de inovação. Só sete anos depois a primeira escola entrou em funcionamento em Lisboa (1918-1919) sem dar inteiro cumprimento ao art. ${ }^{\circ} 114^{\circ}$, seguida um ano depois pelo Porto e por Coimbra ${ }^{37}$. De Évora não há referências.

Durante a Ditadura Militar de 1926/1933 as iniciativas legislativas sobre as escolas normais são constantes. ${ }^{38} \mathrm{O}$ decreto 15.365 de 12 de Abril 1928 visava reduzir as despesas públicas extinguia as escolas normais primárias de Coimbra, Braga e Ponta Delgada, todavia as irrefutáveis taxas de analfabetismo do país (superiores a 50\%) determinou o restabelecimento das referidas escolas. ${ }^{39}$ De Évora continua a não haver referências.

Ora reformula-se a questão do parágrafo anterior: face à convulsão legislativa, efeito da pressão ideológica dos governos, qual o percurso da Escola Normal Primária de Évora? A pesquisa tão-só se encontra na fase incoativa.

\footnotetext{
${ }^{36}$ A reforma do ensino normal primário decretada a 29 de Março de 1910 instituía três escolas normais primárias, em Lisboa, Porto e Coimbra, em regime de coeducação. As novas escolas passavam a ter vários tipos de cursos, tais como Curso Geral, Curso Especial, Cursos Complementares, Curso Colonial e Curso destinado a professores de "alunos diminuídos, intelectuais ou físicos". Esta reforma foi suspensa a 16 de Dezembro, continuando o ensino normal primário a funcionar nos moldes anteriores. A Lei 233, de 7 de Julho de 1914, introduziu alterações quanto à duração do curso, tipo de disciplinas e idade de admissão. Foi suspensa em Junho de 1916 e reiterada a suspensão em Agosto de 1917. Importa considerar a reforma do ensino normal decretada em 10 de Maio de 1919, por conduzir ao encerramento de escolas.

${ }^{37}$ Entre 1925-1926 as Escolas Normais Primárias são cinco: as três referidas e mais a de Braga e Ponta Delgada.

${ }^{38}$ De 1926 a 1936 foram publicados vinte e três normativos legais que contemplam as instituições, os cursos e as matérias.
}

${ }^{39} \mathrm{Cf}$. Decreto n. 15.886, de 21.08.1928 restabeleceu as escolas normais anteriormente extintas. 


\section{O ciclo de vida da Escola do Magistério Primário de Évora}

\subsection{Abertura e encerramento}

No Estado Novo as Escolas do Magistério Primário são sucedâneas das Escolas Normais Primárias por força do Decreto n. 18.646, de 19 de Julho de 1930 (Diário do Governo, I Série, n. 166, 19.07.1930). Sobre a escola de Évora nada se sabe pois a pouca documentação encontrase inacessível, desordenada e suja. Na falta de instalações próprias e adequadas, a escola fica provisoriamente no recolhimento dos religiosos paulistas da congregação da Serra de Ossa ${ }^{40}$. Seis anos depois eram encerradas mediante o Decreto-lei n. 27.279, publicado a 24 de Novembro de 1936 (Diário do Governo, I Série, n. 276, 24.11.1936) e executado pelo ministro Carneiro Pacheco. O diploma legal, suspensivo das matrículas nas escolas do magistério primário, era paradigmático da política educativa do Estado Novo, na sua década de afirmação e radicalização. A justificação foi elaborada oito anos depois, como preâmbulo do texto legal que decretava a reabertura: "O facto de existir um número de diplomados com o curso do magistério primário muito superior às necessidades, no momento, do respectivo serviço conduziu à suspensão da matrícula nas escolas de habilitação para aquele magistério". ${ }^{41}$ E embora o Decreto-Lei 32.243 de 5 de Setembro de 1942 (Diário do Governo, I Série, n. 208, 5.09.1942) as reabrisse para solucionar a enorme carência de professores primários, apenas autorizou estabelecimentos em Lisboa, Porto, Coimbra, Braga e, eventualmente, uma nos Açores, caso se demonstrasse "a sua necessidade", como admitia o ministro Mário de Figueiredo. $\mathrm{O}$ art. ${ }^{\circ} 6^{\circ}$ do Decretolei n. ${ }^{\circ} 33.019$, de 1 de Setembro de 1943 (Diário do Governo, I Série, n. 187, 1.09.1943) autorizou o Ministro da Educação Nacional a criar, por despacho, mais cinco escolas do magistério primário no continente, se houvesse instalação para elas ou se as respectivas juntas provinciais

\footnotetext{
${ }^{40}$ Antigo paço do fidalgo Rui Palha de Almeida, o recolhimento dos religiosos paulistas da congregação da Serra de Ossa foi comprado, em 1578, e remodelado pelo Cardeal Infante D. Henrique.

${ }^{41}$ Cf. Decreto-lei n. 32.243, de 5.09.1942. Diário do Governo, I Série, n. 208 de 5 de setembro de 1942. O diploma não só Determina a reabertura das escolas do magistério primário como também reorganiza os cursos de formação de professores para este nível de ensino.
} 
facilitassem instalações. Na sequência desta determinação foram criadas as Escolas do Magistério Primário de Évora, juntamente com a de Viseu, Faro, Guarda e Bragança, ${ }^{42}$ seguindo a mesma lógica do mínimo suficiente e utilizando argumentos similares.

No jornal eborense Democracia do Sul encontra-se uma notícia sobre a abertura da Escola Primária, intitulada «Exames de Admissão à Escola do Magistério Primário». Cita-se: "Por determinação da Direcção Geral do Ensino Primário terá início em 20 de Setembro a prova a Exame de admissão à Escola do Magistério que vai ser criada nesta cidade". ${ }^{43} \mathrm{O}$ mesmo jornal confirma a notícia a 21 de Setembro e acrescenta que o exame se realizou no liceu André de Gouveia, tendo participado 23 candidatos, cujos nomes são mencionados. O júri era constituído pelos professores António Costa, director da Escola do Magistério Primário, Alfredo Reis ${ }^{44}$ e Aníbal Bruno ${ }^{45} \mathrm{O}$ resultado dos exames foi anunciado no mesmo jornal no dia 30 de Setembro: "Dos 23 candidatos [...] foram admitidos 22 e um excluído. As mais altas classificações - 13 valores - foram obtidas por Angélica A. dos Santos Gouveia e Manuel Inácio Pestana" ${ }^{46}$ nome que se associaria indelevelmente à Escola do Magistério Primário de Portalegre, como Maria João Mogarro destacou na sua dissertação de Doutoramento.

\footnotetext{
${ }^{42}$ Em 1945 foi criada a escola de Vila Real (cf. Decreto-lei n. 35.070, de 26.10.1945. Diário do Governo, I Série, n. 237 de 26 de outubro de 1945) e a de Horta (cf. Decretolei n. 35.227, de 7.12.1945. Diário do Governo, I Série, n. 272 de 7 de 1945). Em 1948 foi criada a escola de Angra do Heroísmo (cf. Decreto-lei n. 36.839, de 19.04.1948).

${ }^{43}$ Cf. s.a., «Exames de Admissão à Escola do Magistério Primário», Democracia do Sul, Ano 42, n. 7784 (Évora, 31 ago. 1943), p. 1.

${ }^{44}$ Alfredo Martins dos Reis (29/01/189 - 09/09/1978) foi nomeado professor de Didáctica e de Legislação na Escola do Magistério Primário de Évora em 1943.do director da Escola Normal do Magistério até 1954 (ver O Leme n. 25 (15 Fev. 1954) p. 714-715).

${ }^{45}$ Cf. Democracia do Sul, Ano 42, n. 7802 (21 set. 1943) p. 1.

${ }^{46}$ Cf. Democracia do Sul, Ano 42, n. 7810 (30 set. 1943) p. 4.
} 


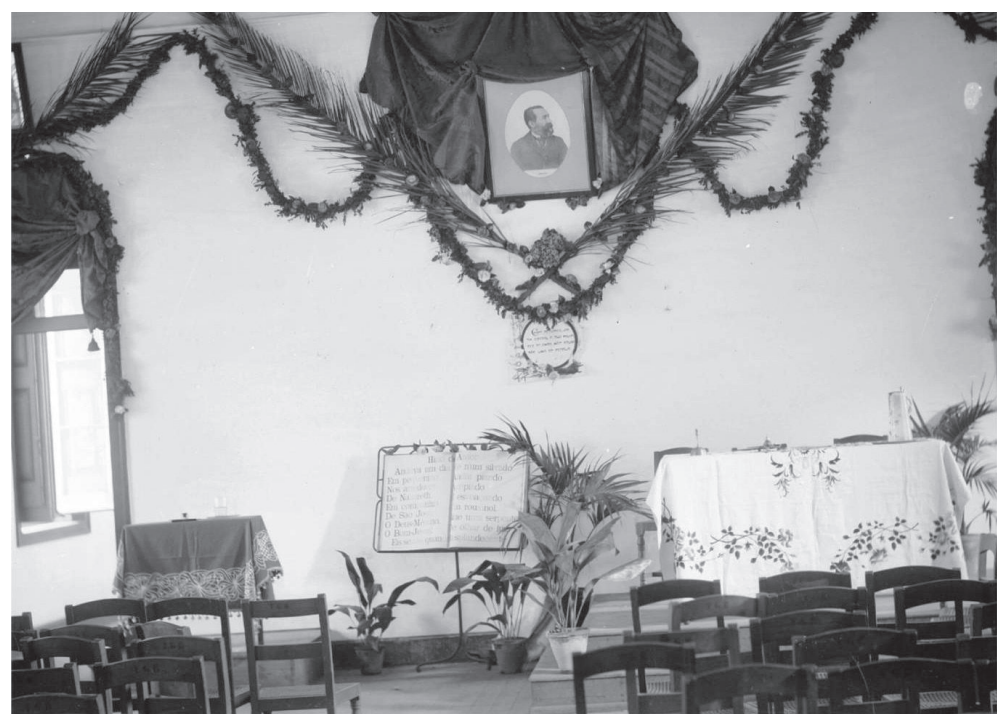

FIGURA 2 - Sala deExposiçãona Escola Normal de Évora(Extinta Igreja Paroquial de S.Pedro)

O facto de o exame se ter efectuado no liceu prova que as instalações da escola não estavam prontas. No periódico consultado pode-se ler a seguinte notícia, datada de 16 de Setembro de 1943:

O comboio-correio procedente de Lisboa, que aqui chega pouco depois do meio dia, traz hoje a Évora o sr. dr. Manuel Cristiano de Sousa, Director-Geral do Ensino Primário e Secundário do Ministério da Educação Nacional, que vem verificar as condições de instalação da nova Escola do Magistério Primário no edifício de S. Paulo e deliberou sobre a escolha de local para o funcionamento da aula da Escola Central Primária que se encontra ali [...]. ${ }^{47}$

A ocupação do edifício do recolhimento dos religiosos paulistas da Congregação da Serra de Ossa foi breve, pois transitaria para o extinto Convento de Santa Mónica, após obras de demolição e de reconstrução. A Escola do Magistério Primário de Évora foi instalada no convento de Santa

${ }^{47}$ Cf. Democracia do Sul, Ano 42, n. 7798 (Évora, 16 set. 1943), p. 1. 
Mónica, ${ }^{48}$ onde funcionara a Escola Primária Oficial, a Cantina Escolar e a Escola do Grupo de Amadores de Música Eborense. ${ }^{49}$

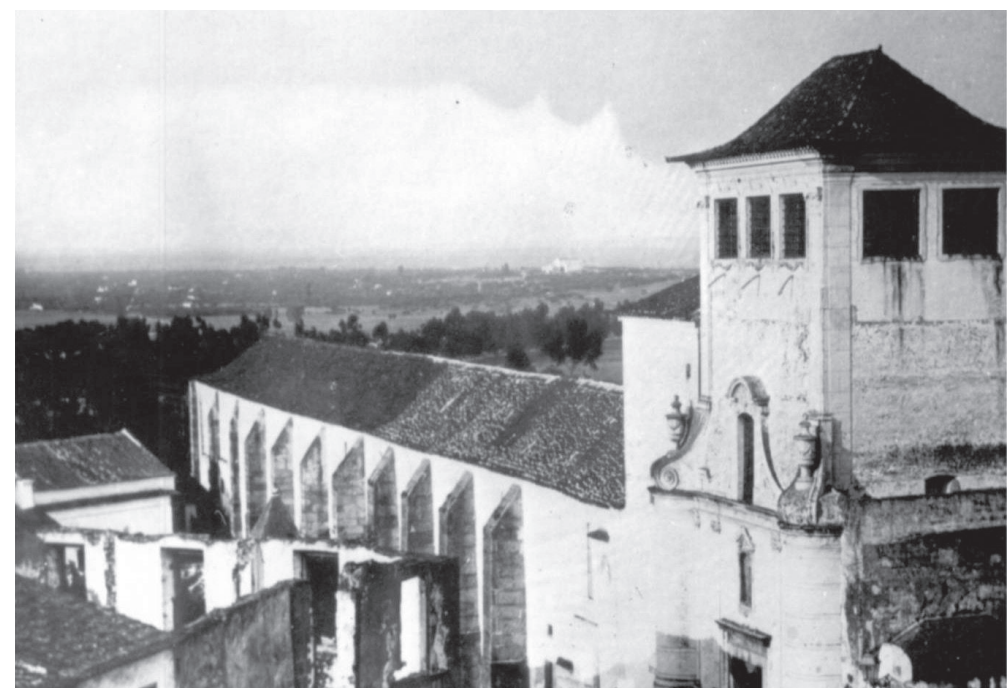

FIGURA 3 - Ruínas do Concento de Santa Mónica, onde se instalou a Escola do Magistério Primário de Évora

A partir daqui é difícil reconstituir a vida da escola pelas razões enunciadas. A Universidade de Évora não tem o arquivo em condições acessíveis nem adequadas, correndo o risco de se perder na totalidade. Por exemplo, não existe nenhum exemplar do jornal estudantil $O$ Leme, publicado entre os anos lectivos de 1952/1953 e 1957/1958, e os que estão na Biblioteca Pública de Évora reúnem-se numa colecção incompleta.

${ }^{48}$ Túlio Espanca informa: "Foi a primeira casa religiosa do sexo feminino da Ordem de Santo Agostinho, em Portugal, e teve os seus primórdios no reinado de D. Fernando. No ano de 1380 duas virtuosas damas eborenses, Constança Xira a Maria Fernandes, moradoras próximo da Igreja paroquial de S. Mamede, instituiu um beatério onde praticavam, juntamente com outras mulheres e donzelas, actos de muita virtude e religião" (cf. Túlio Espanca Inventário Artístico de Portugal. Concelho de Évora, I vol., Lisboa, Academia Nacional de Bellas-Artes, 1966, p. 270). O edifício, cuja igreja era um exemplar manuelino, fora secularizado em 1881. O novo edifício tem uma silhueta clássica atenuada pela brancura das paredes, aduelas e escadaria simples em granito.

${ }^{49}$ Idem, p. 271. 


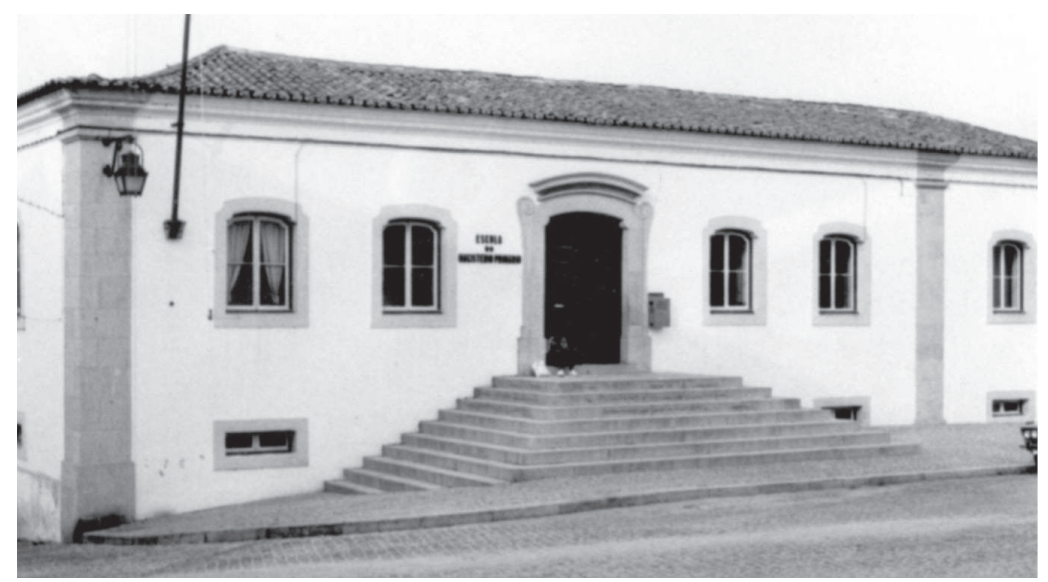

FIGURA 4 - Escola do Magistério Primário de Évora (extinto Convento de Santa Mónica)

Com a revolução de 25 de Abril de 1974 as escolas do magistério primário tiveram de se reorganizar, adequar a situações com novas ordens de exigência e responder a necessidades diversas ${ }^{50}{ }^{5}$ Em cumprimento das Leis 5 e 6, datadas de 1 de Fevereiro 1977, sobre a criação do sistema público préescolar e as escolas normais de educação de infância, iniciou-se em Évora o primeiro ano da Formação de Educadores de Infância, no ano lectivo de 1978/79. ${ }^{51}$ Entretanto o Despacho n. 282/80, de 22 de Agosto (Diário da República, II Série, n. 193, 22.08.1980), determinava a integração das escolas nas Universidades ou nas Escolas Superiores de Educação (ESE), referindose nestes termos: "cada escola do magistério deve encontrar a personalidade

${ }^{50}$ Leia-se o comentário de Rogério Fernandes ao funcionamento das escolas durante este período: "As Escolas do Magistério Primário constituíam um dos sectores mais inovadores e activos do sistema escolar português. Funcionaram com toda a regularidade durante dois dos mais tormentosos anos lectivos. Empenharam-se no trabalho de renovação, com generosidade revolucionária. A sua inserção no meio social e profissional, através do serviço cultural à comunidade e aos próprios professores [...] colocaram as Escolas do Magistério Primário na vanguarda do movimento pedagógico progressista" (cf. Rogério Fernandes, Educação: uma frente de luta. Lisboa, Livros Horizonte, 1977, p. 149).

${ }^{51}$ As escolas abrangidas pelo diploma foram, para além da de Évora, Caldas da Rainha, Fundão, Guimarães, Lamego e Penafiel. 
pedagógica que a caracteriza e qualifica (positiva ou negativamente) perante as instituições congéneres". A Escola do Magistério Primário de Évora integrou-se na Universidade de Évora em consonância com a Portaria n. 507/88, de 28 de Julho. ${ }^{52}$ A sua extinção foi definitiva.

O que resta desta fase? Quase nada. A biblioteca da Escola do Magistério que chegou à Universidade de Évora era constituída por 5716 livros e desses estão catalogados e classificados 4824. Os armários da biblioteca, não se sabe quantos, estão espalhados por vários edifícios universitários. Há ainda um armário e uma estante por classificar. Também a biblioteca pessoal do Professor Marmelo, da escola do magistério, com cerca de 200 a 300 livros e revistas, está por catalogar e classificar. Para se fazer uma ideia do que falta basta dizer que não existem Actas, Avisos, Convocatórias, Correspondência Expedida, Livros de Termos, Livro de Cadastro de Alunos, Livro de Termos de Exame, Lista nominativa dos professores, Livro de Cadastro dos Alunosmestres, Livro de Termos de Posse, Livros de matrículas, Livros de Sumários, Livros de Termos de Exames de Estado, Livro de Termos de Conclusão do Curso de Formação a Educador de Infância, Livros de Termos dos Exames de Saída, Ordens de serviço, Pautas de Aproveitamento, Processos de Alunos, Relatórios, etc. Impressiona a depauperização.

Encontraram-se três Livros de Curso, impressos na Gráfica Eborense e referentes aos anos de 1964-1965, 1969-1971 e 1972-1974. O material que a Universidade tem em reserva é avulso e está guardado em capas A/4 com identificação. Deixa-se a referência:

1. 1975 - Consumo de água

2. 1976 - Educação Física. Programa. Maria de Lourdes Gancho

3. 1978 - Parâmetros de avaliação

4. 1978/1979 - Pedagogia. Maria do Céu Lemos. Importância da noção de tempo na aquisição e reeducação do cálculo.

5. 1978/1979 - Música. Maria Carolina Guerra. Definições

6. 1978/1979 - A observação da actividade didáctica enviada pela D.G.

${ }_{52}$ No $\operatorname{art}^{\circ} 1^{\circ}$ da Portaria n. 507/88, de 28 de Julho, afirma-se: “A Universidade de Évora confere o grau de bacharel em Ensino Primário, ministrando, em consequência, o respectivo plano". As aulas começaram no ano lectivo de 1988/1989. 
7. $1978 / 1979$ - Plano de estudo

8. 1982 - Relatório de Estágio do Curso de Educadores de Infância. Maria João Grade Bravo e Olga Maria Barradas

9. Metodologia e Técnica Pedagógica

10. Educadoras de Infância. Direcção Geral do Ensino Básico FIGURA 5 - Exposição na Escola do Magistério Primário

\section{Conclusão $0^{53}$}

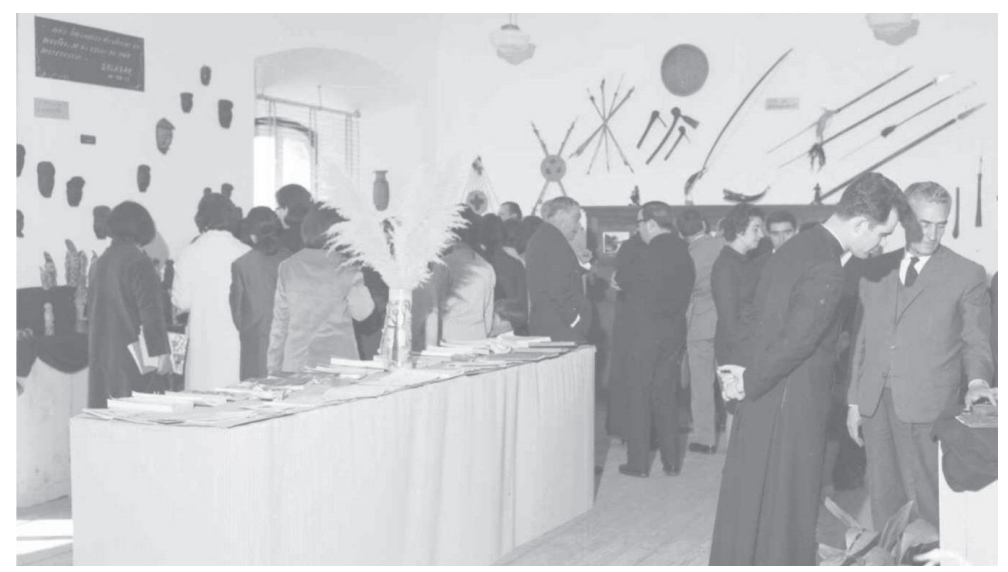

Perante o quadro traçado torna-se pertinente fazer duas considerações. A primeira consideração parte de duas constatações. Uma, do paralelismo dos percursos das escolas: abrem e fecham; abrem e fecham. Outra, de serem sempre instaladas em instituições religiosas e nunca em edifícios construídos de raiz. Uma e outra constatação causam perplexidade e são de imediato associadas à inflexibilidade ideológica ou à impotência da vontade política face aos novos desafios civilizacionais. Por outro lado, tais constatações expressam bem a interdependência entre a educação e os acontecimentos históricos, reforçando o princípio teórico grego de que toda a educação é política. Embora a educação se configure no plano político

${ }^{53}$ Este trabalho não se poderia realizar sem a preciosa ajuda de Carmem Almeida, Susana Sardinha e os funcionários da Biblioteca Geral da Universidade de Évora. O agradecimento fica expresso publicamente. 
e a política se expresse na educação, a relação entre ambas resiste quase sempre ao desenvolvimento, ao acesso da humanidade à vida plena, quer no plano individual quer no plano da vida colectiva. A história da relação entre educação e política é a história oculta ou emergente das relações de poder.

A segunda consideração visa responder à seguinte questão: Por que razão é difícil fazer a história das Escola Normal e da Escola do Magistério Primário? A integração do legado destas duas escolas na Universidade de Évora, a necessidade de utilizar as instalações para outros serviços, a dispersão do antigo corpo docente e a reestruturação do curso provocaram, no seu conjunto, um imediato desinteresse por tudo o que a elas dizia respeito, agravando o esquecimento decorrente da extinção e pauperizando a partilha de uma herança educativa comum. Face a esta situação de desconsideração pelo plano da materialidade da cultura escolar, por um lado, e, por outro, de obstaculização à investigação em História da Educação, dificilmente se pode proceder ao levantamento, categorização e preservação do material subsistente. $\mathrm{O}$ que se conseguiu apresentar não são mais que peças de um puzzle incompleto. É lamentável que uma instituição mal trate a memória de uma outra e não compreenda que, como escreve Margarida Felgueiras, "a memória é passado em acção". 54

\section{Referências $^{55}$}

AFONSO, Natércio. A reforma da administração escolar. A abordagem política em análise organizacional. Lisboa, Instituto de Inovação Educacional, 1995.

ALBUQUERQUE, Luís de, «Notas para a História do ensino em Portugal», in Estudos de História, vol. VI, Coimbra, Universidade de Coimbra, 1978.

CARVALHO, Rómulo de, História do Ensino em Portugal - desde a fundação da nacionalidade até ao fim do regime de Salazar-Caetano,

\footnotetext{
${ }^{54} \mathrm{Cf}$. Margarida Felgueiras, A Escola Primária: entre a Imagem e a Memória, Porto, s.e., 2000 , p. 50.

${ }^{55}$ Este trabalho é parco em citações de autores, o que não corresponde de todo ao desconhecimento das suas obras ou à falta de leitura das mesmas. Tratou-se de uma opção determinada pelo número de páginas estabelecido. Haverá ocasião de proceder a um desenvolvimento das problemáticas inerentes que se sustentará nesses autores.
} 
Lisboa, Fundação Calouste Gulbenkian, 1986.

FELGUEIRAS, Margarida, «O projecto "Para um museu vivo da escola primária", in A Escola Primária: entre a Imagem e a Memória, Porto, s.e., 2000, p.9-30.

FERNANDES, Rogério, Ensino: sector em crise, Lisboa, Prelo Editora, 1967.

FERNANDES, Rogério. Os caminhos do ABC. Sociedade portuguesa e ensino das primeiras letras. Porto, Porto Editora, 1994.

GODINHO, Vitorino Magalhães, A educação num Portugal em mudança, Lisboa, Edições Cosmos, 1975.

GOMES, Joaquim Ferreira, «Escolas normais para habilitação de professores primários», Estudos para a história da educação no séc. XIX, 2. ${ }^{\mathrm{a}}$ ed. Lisboa, Instituto de Inovação Educacional, 1996, p. 11-59.

MAGALHÃES, Justino, «Contributo para a história das instituições educativas - entre a memória e o arquivo», A reforma Jaime Moniz. Colóquio comemorativo dos 100 anos, Braga, Sociedade Portuguesa de Ciências da Educação, 1998.

MATOS, Manuel, "Escolas do magistério primário: uma experiência apunhalada", O Professor (nova série), n. 5, fevereiro1978, p. 39-44.

MOGARRO, Maria João, "História e memória da escola", Aprender Revista da Escola Superior de Educação, n. 22, julho de 1999, pp. 139-142. MÓNICA, Maria Filomena, Educação e Sociedade no Portugal de Salazar (A escola primária salazarista, 1926-1939), Lisboa, Editorial Presença/ Gabinete de Investigações Sociais, 1978.

NÓVOA, António, "A história do ensino primário em Portugal", in Primeiro Encontro de História da Educação em Portugal-Comunicações, Lisboa, Fundação Calouste Gulbenkian/Serviço de Educação, 1988, p. 45-64. NÓVOA, António, «Introdução», in Reformas do Ensino em Portugal. Reforma de 1911, Tomo II, vol. I. Lisboa, Instituto de Inovação Educacional, 1989.

NÓVOA, António, «Para uma análise das instituições escolares», in NÓVOA, António (coord.), As organizações escolares em análise, Lisboa, Publicações Dom Quixote/IIE, 1992, p. 13-43.

Educ. e Filos. Uberlândia, v. 23, n. 46, p. 73-98, jul./dez. 2009. 
PINHEIRO, J. E. Moreirinhas, Elementos para o estudo da Escola Normal Primária de Lisboa, Lisboa, Escola Superior de Educação de Lisboa, 1995.

PINTO, Cabral, «A contra-reforma das escolas do magistério primário», $O$ Professor (nova série), n. 2, novembro1977, p. 13-16.

PINTO, Cabral, «Repor as escolas do magistério no caminho de Abril», $O$ Professor (nova série), n. 21, outubro1979, p. 4-5.

RIBEIRO, Luís, Escolas do Magistério Primário: andar para trás em nome de quê?», Jornal de Educação, n. 2, maio de 1977, p.30-31.

STOER, Stephen R., Educação e mudança social em Portugal, 1970-1980. Uma década de transição, Porto, Edições Afrontamento, 1986.

Data de registro: $15 / 02 / 09$

Data de aceite: 06/04/09 
